\title{
Quality and Emission Analysis of Charcoal from Various Species of Wood Using Improved Carbonization
}

\section{Technologies in Kenya}

\author{
Nellie Oduor ${ }^{1}$, Emily Kitheka ${ }^{1}$, Celestine Ingutia ${ }^{1}$, Nathan Nyamai ${ }^{1}$, James Kimwemwe ${ }^{1}$ and Kevin Juma ${ }^{2}$ \\ 1. National Forest Products Research Programme (NFPRP), Kenya Forestry Research Institute, Nairobi 64636-00620, Kenya \\ 2. The Nature Conservancy, Africa Regional Office, 31 El Molo Drive, off Maji Mazuri Road, Lavington, Nairobi 19738-00100, Kenya
}

\begin{abstract}
Biomass energy provides over $70 \%$ of the national energy demand in Kenya. Increased demand has contributed to increased environmental degradation through deforestation, contributing significantly to the global emissions of greenhouse gases, loss of habitats, and biodiversity, and increased health risks. Efficient charcoal conversion technologies have been researched and developed. However, no studies have been undertaken to establish the influence of the improved technologies on the quality of charcoal produced and the emission levels of greenhouse gases from each kiln. The study was undertaken (in eastern Kenya) to determine the effect of carbonization technology and tree species on the quality of the charcoal, the emission levels of the kilns, and the energy properties of the charcoal from various selected species. A total of 14 species were sourced for the study and carbonized using the Adams retort, portable metal, improved earth and the traditional earth kilns. The results indicated that Balanites aegyptiaca, Terminalia spinosa, Acacia nilotica and A. tortilis were ranked best indigenous species in terms of calorific values with mean calorific values above $6.0 \mathrm{kcal} / \mathrm{g}$ while Prosopis juliflora, Casuarina equistifolia and Eucalyptus camadulensis were the best exotic species with mean kcal/g of $6.430 \mathrm{kcal} / \mathrm{g}, 5.972 \mathrm{kcal} / \mathrm{g}$ and $5.633 \mathrm{kcal} / \mathrm{g}$ respectively. Analysis of variance on the energy values indicated there was no significant difference in the quality of charcoal produced using the different kilns. The improved earth kiln and the portable metal kiln produced charcoal that was more dense and intact. Charcoal from the preferred indigenous species had also the longest burning time with a mean of 124 minutes compared to 62.4 minutes for the exotics. The highest burning temperature was found in the indigenous species. Results on emission tests were conducted using a portable gas analyzer on the four kiln types. The carbon dioxide emissions were rather high. Methane production in all kilns showed an upward trend at the beginning of the carbonization process and towards the end, the levels declined. The study concluded that a number of species are overexploited for charcoal production with no conservation measures being undertaken thus being threatened with extinction. The types of kiln have significant effect on the energy values (calorific values) of charcoal. The quality of charcoal using improved kilns gave high calorific values. Emission levels for all kiln types were generally high. The study recommends further research on all improved charcoal conversion technologies for reduced emission of greenhouse gases especially retorts since they utilize the flue gases.
\end{abstract}

Key words: Charcoal production, charcoal kilns, greenhouse gases, calorific values.

\section{Introduction}

Globally, over 3 billion people rely on burning traditional biomass fuels such as wood, dung and crop residues for cooking, lighting and heating $[1,2]$. Biomass energy is a main type of renewable energy and is key in supporting the global SDGs (Sustainable

Corresponding author: Nellie Oduor, MSc, research scientist and NFPRP programme director, research fields: forest products research with emphasis on promoting biomass energy, bamboo utilization and wood treatment/protection.
Development Goals) in the framework of energy security, climate action and reduced poverty. The demand for biomass energy is rising worldwide due to demographic changes, increasing urban migration and increased demands in the commercial sectors. In Kenya, biomass energy in forms of fuel wood, charcoal and agricultural wastes is a major source of energy for millions of people, providing over $70 \%$ of the national energy demand for cooking and heating [3]. Over $90 \%$ of rural households depend on firewood for cooking 
and heating while in urban areas, charcoal is a key source of energy providing 82 percent of urban and 34 percent of rural household respectively [4]. Wood fuel based enterprises are increasingly becoming important sources of livelihoods and the sector also provides employment and income for over one million people who support over two million dependants [5,6]. Apart from being sources of fuel for domestic use, wood fuel is also an important source of energy for SMEs (Small and Medium Sized Enterprises). Charcoal production is also an important fall back strategy in ASALs (Arid and Semi-Arid Lands) especially during prolonged droughts due to climate change.

In Kenya, biomass energy consumers derive their energy requirements from wood fuel energy obtained from unsustainable sources thus contributing to increased deforestation and over exploitation of preferred tree species. Currently, there exists a growing imbalance between supply and demand of biomass energy. It is estimated that the national demand of charcoal in Kenya is over 16 million $\mathrm{m}^{3}$ while supply is estimated at about 13.5 million $\mathrm{m}^{3}$ [7]. Currently, the deficit stands at over 60\% [8]. However, utilization and processing of the biomass is characterized by use of cook stoves and kilns whose efficiencies are low ranging between $8-15 \%$ for kilns $[7,9,10]$. The increased demand for biomass energy has also contributed to increased environmental degradation through deforestation and over exploitation of woody resources, also contributing significantly to the global emissions of greenhouse gases, loss of habitats and biodiversity, and increased health risks - respiratory, waterborne and deficiency diseases. Various technologies with high charcoal conversion efficiencies and quality charcoal have been researched and developed. However, according to several studies, uptake of these improved technologies has been low among charcoal producers due to number of factors, chief among them is the high cost of improved technologies, lack of information and skills on the technologies, and the cultural preferences for traditional technologies among others [11]. However, no studies have been undertaken to establish the influence of the improved technologies on the quality of charcoal carbonized using various technologies and the emission levels of greenhouse gases such $\mathrm{CO}$ (Carbon Monoxide), $\mathrm{CO}_{2}$ (Carbon Dioxide) and methane from each kiln type.

The study sought to document preferred tree species for charcoal production, tree conservation measures by the local community, establish the effect carbonisation technologies and tree species have on the quality of the charcoal. The study also sought to determine the emission levels of the kilns, and to establish the energy properties of the charcoal from various selected preferred indigenous and exotic species. These species included Pinus patula (Pines), Cupressus lusitanica (Cypress), Casuarina equistifolia, Senna siamea, Melia volkensii (Mukau) and Grevillea robusta planted as woodlots whose thinning's and pruning's at certain ages would serve as alternative sources of wood for charcoal production.

\section{Materials}

The study was undertaken in Kitui and Machakos Counties and involved procurement of wood materials from fourteen different tree species both exotic and indigenous. Information on preferred species for charcoal production by local communities was obtained using a structured questionnaire. Equipment used included a portable gas analyser, moisture meter and a gun thermometer carbonizing kilns improved cook stoves and bomb calorimeter. Collected woods were stacked to dry for two months. After stacking and drying of the wood, carbonization was done using different carbonization technologies. These were the traditional kiln, the improved earth kiln, the Adams retort and portable metal kiln. Emissions levels of flue gases $\mathrm{CO}, \mathrm{CO}_{2}$ and methane were measured using the portable gas analyser. Tests to determine the energy properties (calorific values, fixed carbon, moisture content and ash content) of charcoal from the 14 tree species were carried out. 


\section{Results and Discussions}

\subsection{Preferred Tree Species for Charcoal Production in Dry Land Kenya}

Results indicated that a number of tree species are preferred and exploited for charcoal production by the local communities. These species include Acacias, Terminalias, Combretum, Senna abbreviata and Newtonia hildebrandtii species among others as summarized shown in Table 1.

These species are found naturally in the woodlands and as scattered trees on farms where they are indicated as moderately available. However, habitat destruction through expanding agricultural activities, overexploitation and selective harvesting of the species for wood fuel production has affected their natural regeneration. Earlier studies on impact of charcoal production on species diversity and composition in selected charcoal production hotspots in Kitui County $[12,13]$ indicate overexploitation of preferred species through selective harvesting. This has negatively impacted on species diversity in areas of heavy charcoal production. The dense high quality charcoal was indicated as one of the major reasons for the preference by the charcoal producers and consumers. Others include good market prices, the charcoal lasts longer while cooking and only a small amount of charcoal was required for cooking as depicted in Fig. 1.

Due to the selective harvesting leading to overexploitation, a number of species were indicated as endangered and are no longer readily available, while others existed only as small trees thus affecting their capacity to naturally regenerate. These species include Terminalia spinosa (mutala), Dalbergia melanoxylon (Muvingo), A. Mellifera (Muthia), Acacia gerrardii (Munina), Tamarindus indica (Kithumula) and Albizia amara (Kyundua).

\subsection{Why Preferred Species Are Not Planted on Farms}

Despite the over exploitation of the preferred tree species by the community, very few conservation measures were indicated as being undertaken to preserve the indigenous tree resources. The indigenous trees are hard woods and thus over exploited for multiple uses such as fencing posts, firewood, carving, and building among other uses. Over $90 \%$ of the respondents indicated they plant trees as woodlots for multiple uses, however very few (7\%) use indigenous species due to lack of knowledge and skills on how to propagate them in their own nurseries. Other reasons are as summarized in Fig. 2.

Table 1 List of preferred tree species by local community for charcoal production.

\begin{tabular}{lllll}
\hline Name of species (botanical) & (Local name-Kikamba) & $\begin{array}{l}\text { Quality } \\
\text { charcoal }\end{array}$ & $\begin{array}{c}\text { of Percentage } \\
\text { preference }\end{array}$ & Other uses \\
\hline Acacia mellifera & Kithia & Excellent & 24.6 & Fencing material, firewood \\
Acacia tortilis & Mwaa & Excellent & 20.1 & Firewood, fodder \\
Senna abbreviata, & Kyathandathe & Excellent & 14.2 & Firewood \\
Acacia eliator & Muswiswi & Excellent & 9.2 & Firewood, \\
Newtonia hildebrandtii & Mukame & Excellent & 8.2 & Firewood \\
Terminalia prunoides & Mutoo & Very good & 7.4 & Firewood, fencing poles \\
Acacia horrida & Mukaiki & Very good & 5.4 & Firewood, fodder \\
Acacia nilotica & Musemei & Very good & 3.2 & Firewood, fodder \\
Balanites aegyptiaca & Kilului & Good & 2.2 & Firewood, fodder, \\
Terminalia brownii & Muuku & Good & 1.7 & Firewood, carving \\
Terminalia spinosa & Mutala & Good & 1.2 & Ornamental, carving \\
Acacia polyacantha & Musewa wa kisungu & Good & 1.1 & Firewood, fencing material \\
Zanthoxylum chalybeum & Mukenea & Fair & 0.7 & Indigenous colour \\
Albizia amara & Kyundua & Fair & 0.5 & Firewood \\
Mangifera indica & Muembe & Fair & 0.3 & Fruits, carving \\
\hline
\end{tabular}




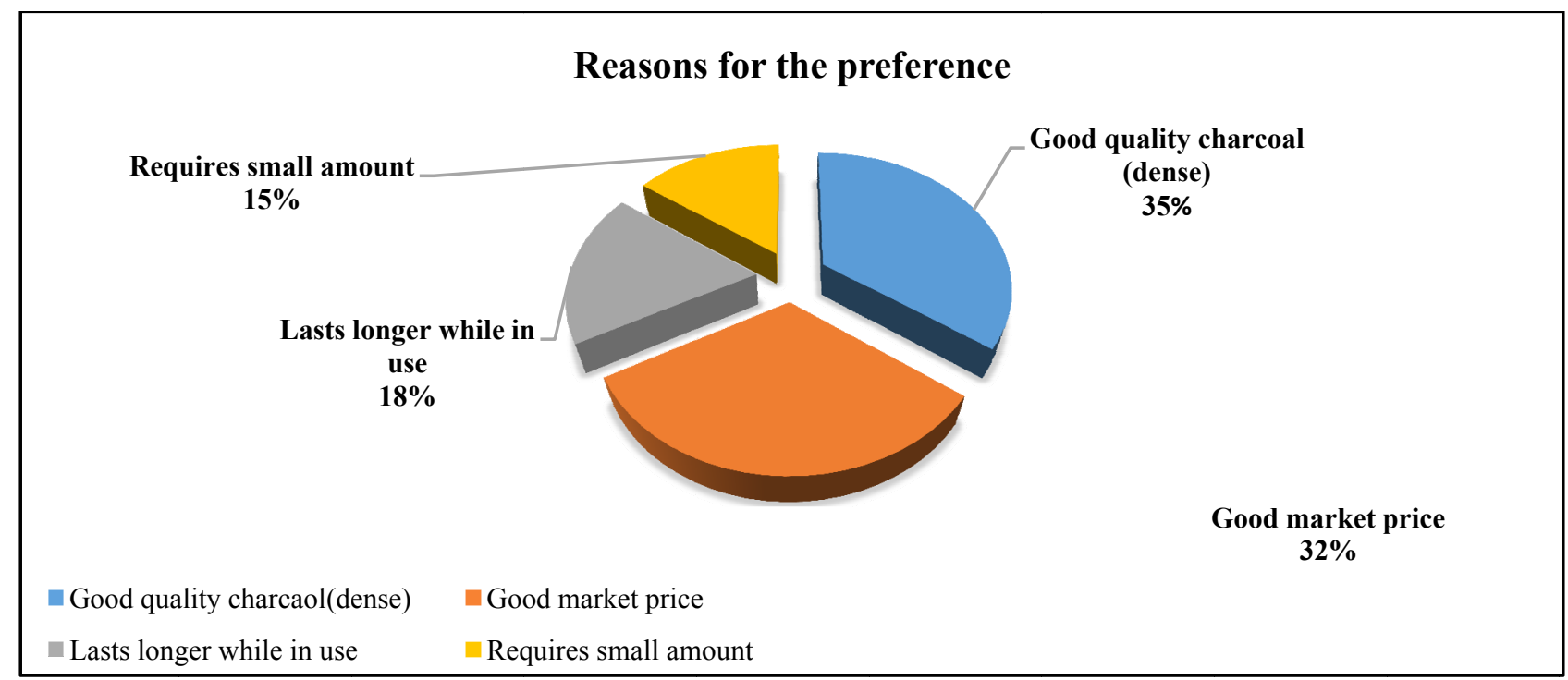

Fig. 1 The reasons for preference of indigenous species for wood fuel production.

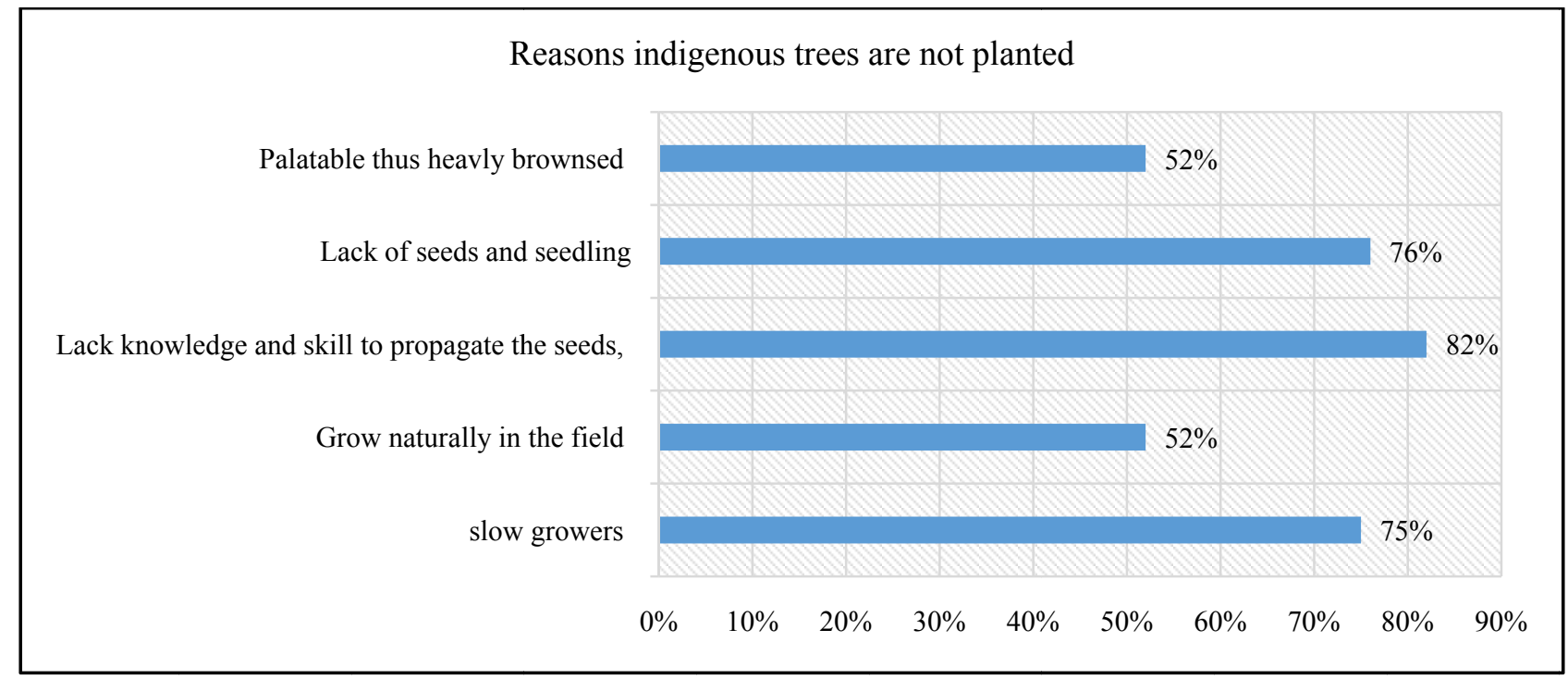

Fig. 2 Reasons indigenous species are not planted on farms.

With increased human population, encroachment and overstocking in the rangelands, the indigenous species are exposed to intense browsing by domestic and wildlife animals, and thus remain as stunted shrubs instead of growing into fully grown trees.

\subsection{Tree Planting on Farms}

About $85 \%$ of the respondents indicated that they have established boundary planting and woodlots using exotic species. These exotic species include the Eucalyptus species, Grevillea robusta, Casuarina equistifolia, Jacaranda mimosifolia, Delonix regia,
Cupressus lusitanica and Senna siamea among others. Their availability in local community nurseries, fast growth and drought tolerance were indicated for their preference as indicated in Table 2. From the established trees, wood fuel products come only as a byproduct after the trees have been harvested for other purposes.

\subsection{Emission Tests Results}

Charcoal production and increased deforestation have been indicated as among key drivers to global warming through increased release of greenhouse 
Table 2 Reasons for preference of exotic tree species for woodlot establishment or boundary planting.

\begin{tabular}{lll}
\hline Species & Reasons for preference & Percentage preference (\%) \\
\hline Melia volkensii & Good quality timber and fast growing & 68 \\
Eucalyptus species & Fast growing, multiple uses & 62 \\
Grevillea robusta & Fast growing, agro, forestry tree, available in community nurseries, & 54 \\
Senna siamea & good coppice ability & 73 \\
Casuarina equistifolia & Drought tolerant, available in community nurseries, fast growing & 36 \\
Jacaranda mimosifolia & Poles and border planting, quality charcoal & 28 \\
Delonix regia & Ornamental, fast growing, drought tolerant & 25 \\
Cupressus lusitanica & Ornamental, windbreak & 17 \\
\hline
\end{tabular}

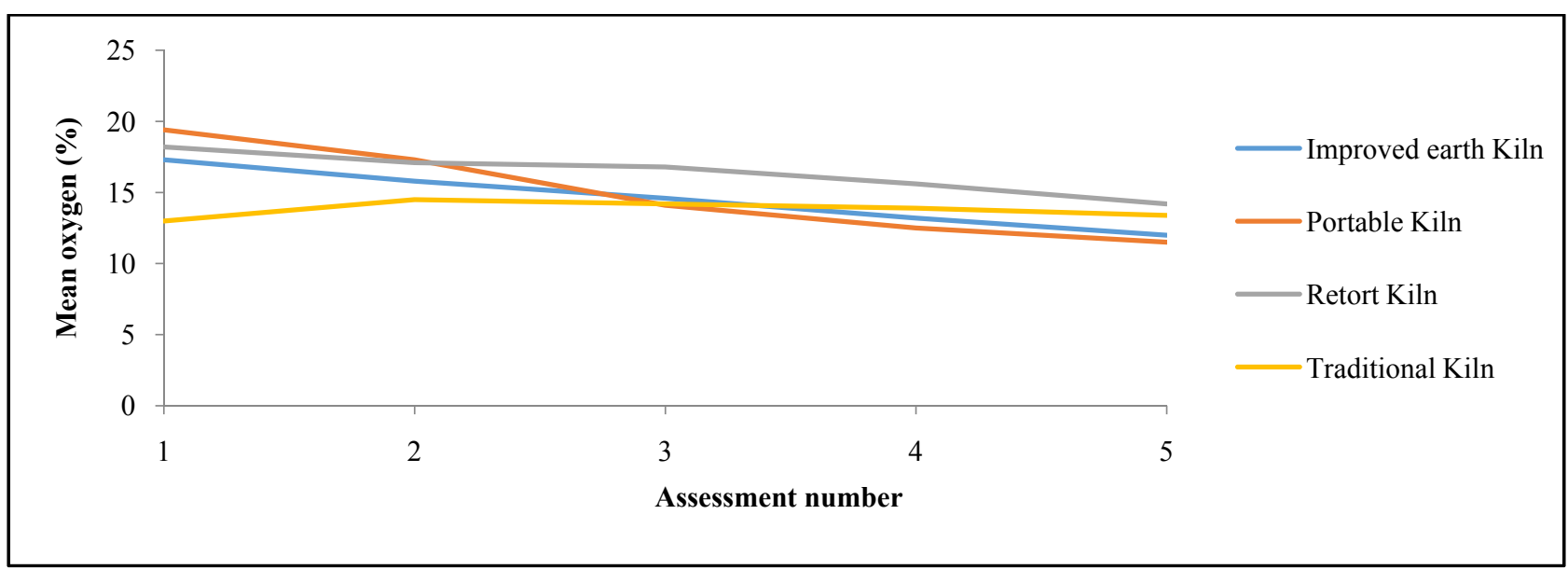

Fig. 3 Oxygen levels of four different kilns carbonizing Terminalia brownii.

gases $\left(\mathrm{CO}_{2}, \mathrm{CO}\right.$ and methane) into the atmosphere. Use of improved kilns for wood conversion has been indicated as contributing to improved environmental conservation through improved recovery rates (thus fewer trees are being cut for charcoal production). However, harvesting and conversion of trees resources to carbon materials leads to increased emission levels of greenhouse gases. Emissions tests were conducted on three improved kiln types using two tree species (Prosopis juliflora and Terminalia brownii) using a gas analyser model (BTU900-Serial Number 4885 of USA). Assessments were taken at an interval of two hours and the number of assessments depended on the kiln type that determined the duration of carbonization process.

\subsubsection{Emission levels of Oxygen $\left(\mathrm{O}_{2}\right)$}

Combustion is a chemical process in which fuel materials or substances react rapidly with $\mathrm{O}_{2}$ and give off heat. In any normal combustion process, $\mathrm{O}_{2}$ supports the chemical processes that occur during combustion and this will lead to decreased $\mathrm{O}_{2}$ levels. The results indicate that oxygen level in all the four kilns (traditional, improved earth, portable and retort kilns) for both species declined during the carbonization process (Fig. 3). However, for the traditional kiln, the decline was irregular due to absence of a particular vent for air control.

Carbonization process is carried out in limited $\mathrm{O}_{2}$. Therefore, it was important to monitor the levels of $\mathrm{O}_{2}$ in the kilns. From the results there was a slight decrease in the $\mathrm{O}_{2}$ levels as shown in Fig. 3.

3.4.2 Emission Levels of Carbon dioxide $\left(\mathrm{CO}_{2}\right)$

Carbon dioxide $\left(\mathrm{CO}_{2}\right)$ is one of the most important greenhouse gases as it absorbs heat energy that is radiated from the earth's surface and prevents it from escaping into space, thus keeping the earth warmer than it should be. The increased level of $\mathrm{CO}_{2}$ in the atmosphere from anthropogenic activities that burn 
carbon such as charcoal production and deforestation increases its level thus escalating its greenhouse effect. $\mathrm{CO}_{2}$ and $\mathrm{CO}$ are by-products of any combustion process including carbonization. It is caused by the complete burning of any substance containing carbon. In combustion of fuel material, oxidation of the carbon materials leads to production of $\mathrm{CO}_{2}$ and $\mathrm{CO}$. The results indicated that $\mathrm{CO}_{2}$ levels in both species and in all kilns are generally high during the carbonization process as indicated in Fig. 4, however the composition of the flue gases is highly interfered with by the changing wind directions except for retort kiln. The $\mathrm{CO}_{2}$ levels generally increased and then lowered as the carbonization levels progressed to completion. It was noted that the portable metal and improved earth kilns had high peaks of $16 \%$ and $12 \%$. This could be attributed to the fact that the measurement of these flue gases was through the chimneys - a concentration of gases.

\subsubsection{Emission Levels of Methane}

Methane gas is one of the greenhouse gases contributing to global warming after $\mathrm{CO}_{2}$. It is the primary component of natural gas and can also be produced from organic materials such as livestock, agricultural wastes and from decay of wastes from municipal solid wastes landfills. Increased levels of methane gas in the atmosphere lead to warming up as it absorbs sun's heat thus warming the atmosphere thus it is considered an important greenhouse gas.
From the results, generally there is an upward trend of methane production during the carbonization process. The downward trend of the two exotic species in the beginning is due to high temperatures that were burning most of the available methane gas but with time more methane was dislodged from the wood material but combustion capacity of the same was declining thus the upward trend.

The results indicated an upward trend at the commencement of the process (Fig. 5). The levels then decline as these gases are consumed in the carbonization process. It will be noted that for the retort kiln it was lowest as the methane gas is burnt in the recycling of the flue gases.

\subsection{Energy Values of Charcoal from Selected} Preferred Species

Fuel properties (calorific value, moisture content, volatile matter, and ash content) results are usually among the key parameters used to determine the quality of fuel material such as charcoal or briquettes. The results indicate that Balanites aegyptiaca, Terminalia spinosa, Acacia nilotica and Acacia tortilis in that order were ranked as the best indigenous species in terms of calorific values with mean calorific values above $6.0 \mathrm{kcal} / \mathrm{g}$ while Prosopis juliflora, Casuarina equistifolia and Eucalyptus calmaldulensis in that order were the best exotic species with mean $\mathrm{kcal} / \mathrm{g}$ of $6.430 \mathrm{kcal} / \mathrm{g}, 5.972 \mathrm{kcal} / \mathrm{g}$ and $5.633 \mathrm{kcal} / \mathrm{g}$ respectively

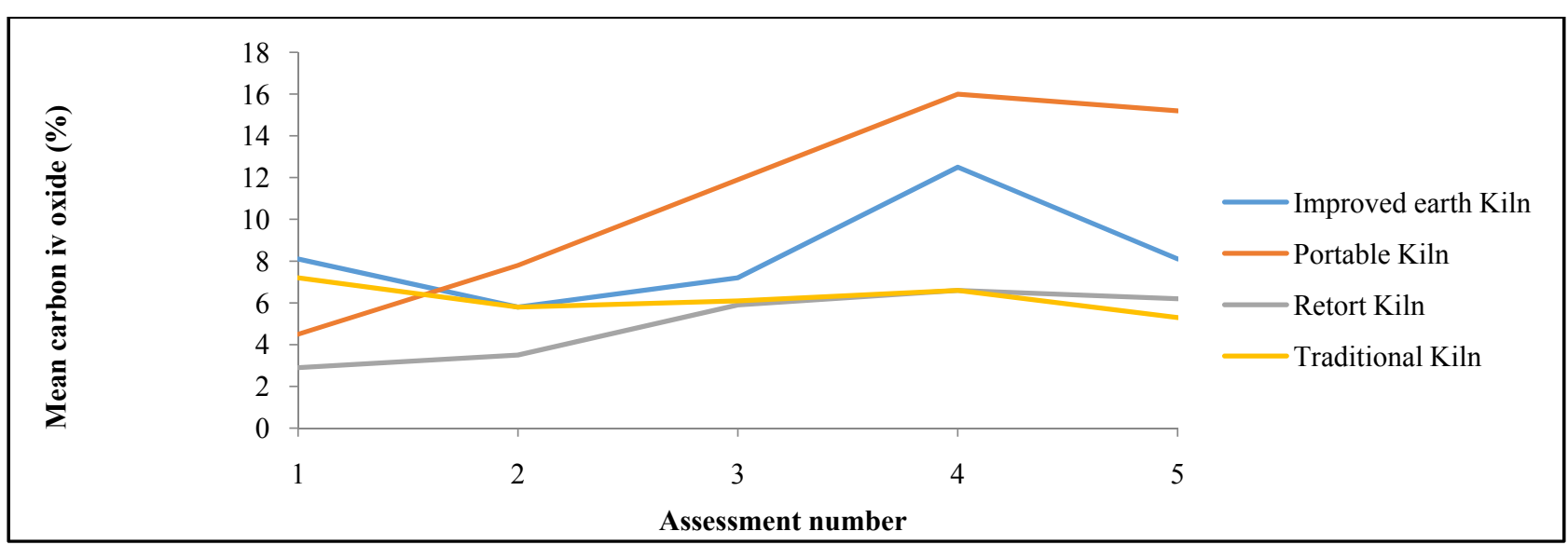

Fig. $4 \mathrm{CO}_{2}$ levels of four different kilns carbonizing Terminalia brownii. 


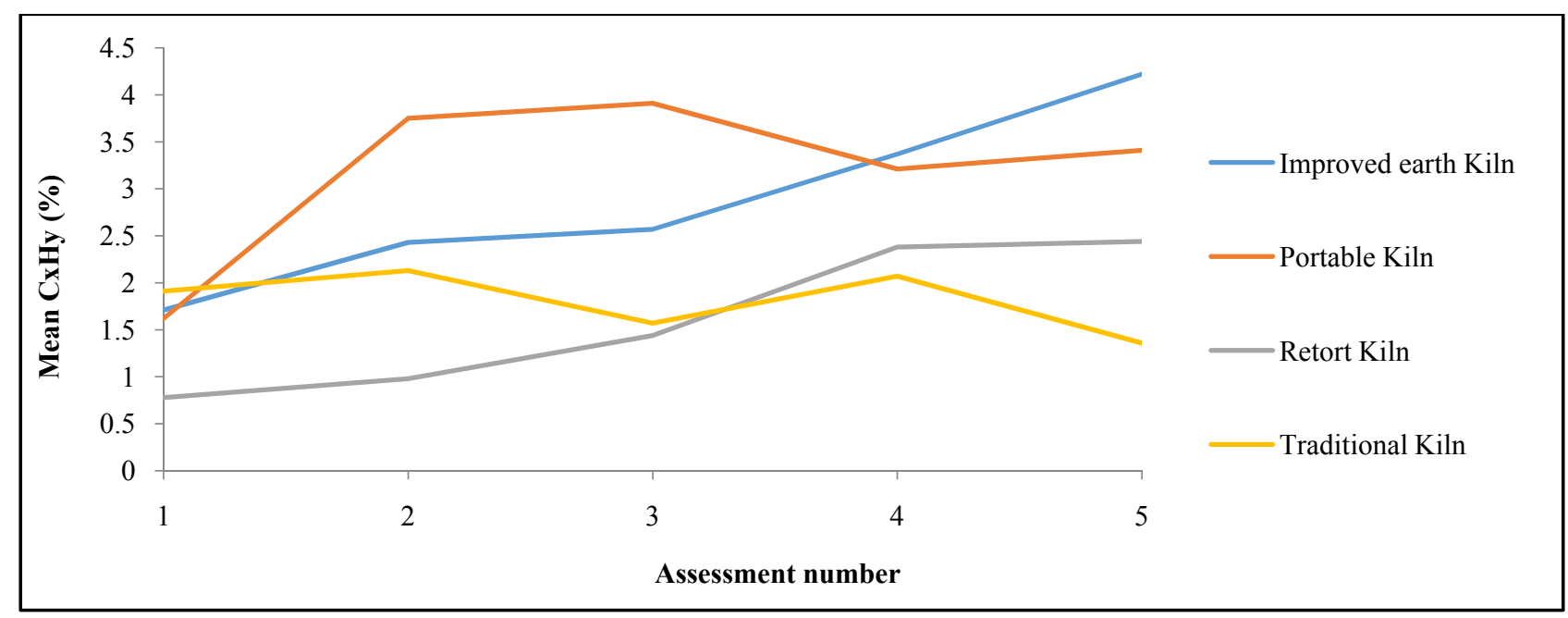

Fig. 5 Methane levels of four different kilns carbonizing Terminalia brownii.

Analysis of variance performed indicated there was no significant difference in the quality of charcoal carbonized using the different kilns.

\subsubsection{Analysis of Variance}

ANOVA was performed to test whether there was significant difference among the four types of kilns in terms of percent moisture content, fixed carbon, volatile matter, ash content and calorific values ( $\mathrm{kcal} / \mathrm{g})$. A test for multiple comparisons using Turkey's post hoc test was also done. A critical value of $\alpha=0.05$ was set and a $p$-value obtained.

The results indicate that there was no significant difference in the quality of charcoal carbonized using different kilns in terms of energy values however, the physical characteristic of the charcoal was good and intact among charcoal produced using all improved kilns compared to traditional. Among the technologies, the improved earth kiln and the portable metal kiln had best charcoal among the improved technologies,

According to FAO Forestry Paper 63, of 1985 [14] it gives specifications for a good quality charcoal as follows: moisture content should range between $5-15 \%$; volatile matter 5-40\%; ash content should average $3 \%$; the fixed carbon should range between $50-95 \%$, generally calorific value for charcoal ranges between $5-9 \mathrm{kcal} / \mathrm{g}$. Energy values for calorific value, moisture content, volatile matter, and ash content for each species and kiln type was determined. The best indigenous and exotic species are shown in Table 3.

\subsection{Calorific Values of Selected Indigenous and Exotic} Tree Species Carbonized Using Different Kilns

\subsubsection{Indigenous Species}

The calorific values of selected indigenous species carbonized using the four kiln types are shown in Fig. 4. The results showed no significant difference in the calorific values between the kiln types.

\subsubsection{Exotic Species}

Fig. 7 shows the calorific values of selected exotic species carbonized using the four kiln types. There was no significant difference in the calorific values between the kiln types.

\subsection{Burning Time and Heat Value of Charcoal from Selected Tree Species}

The burning time and the highest temperature attained of the burning charcoal in the KCJ (Kenya Ceramic Jiko) cook stove were measured for all species. The results are as presented in Fig. 8. The results indicate that a species can have very high temperature values but burn out within a very short time. Acacia polyacantha and Cupressus lusitanica are good examples of this trend. Such species can be promoted for briquette making where its bulk density will cause them to burn for longer periods. 

Technologies in Kenya

Table 3 Energy values for the charcoal from the selected wood species.

\begin{tabular}{llllll}
\hline Species & $\begin{array}{l}\text { Moisture content } \\
(\%)\end{array}$ & $\begin{array}{l}\text { Volatile matter } \\
(\%)\end{array}$ & Ash content (\%) & Fixed carbon (\%) & $\begin{array}{l}\text { Calorific values } \\
(\mathrm{kcal} / \mathrm{g})\end{array}$ \\
\hline Balanites aegyptiaca & 4.81 & 16.36 & 2.94 & 75.84 & 6.344 \\
Terminalia spinosa & 5.33 & 11.85 & 5.11 & 77.7 & 6.290 \\
Acacia nilotica & 5.10 & 14.2 & 4.18 & 76.5 & 6.022 \\
Acacia tortilis & 5.93 & 10.02 & 4.13 & 79.99 & 5.799 \\
Prosopis juliflora, & 5.21 & 12.97 & 5.19 & 76.54 & 6.430 \\
Casuarina equistifolia & 4.59 & 12.66 & 3.32 & 79.31 & 5.972 \\
Eucalyptus camadulensis & 7.34 & 12.82 & 1.87 & 77.95 & 5.633 \\
\hline
\end{tabular}

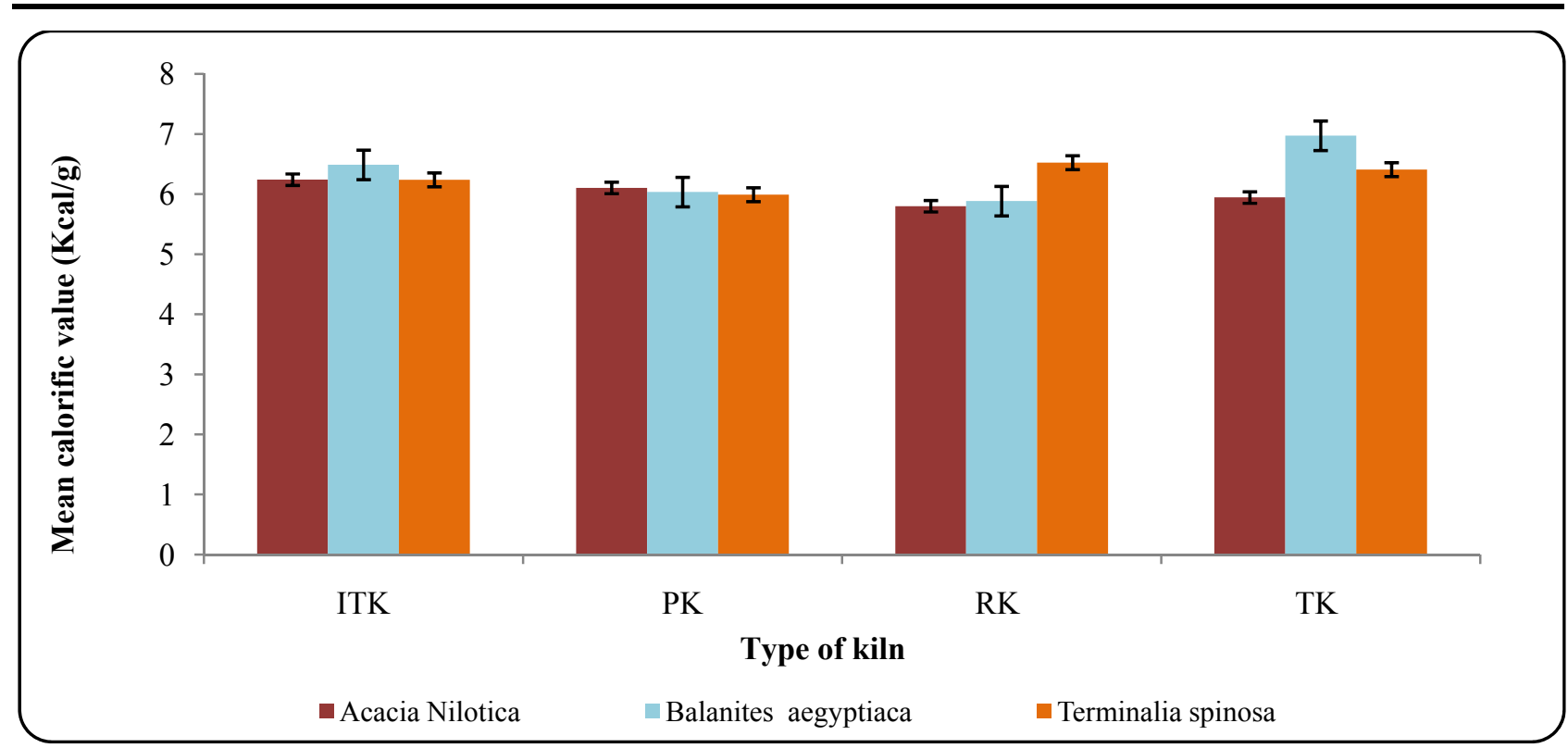

Fig. 6 Graphic presentation of calorific values of three indigenous species carbonized using different kilns.

Note: ITK—Improved Earth Kiln; PK—Portable Kiln; RK—Retort Kiln; TK—Traditional Kiln.

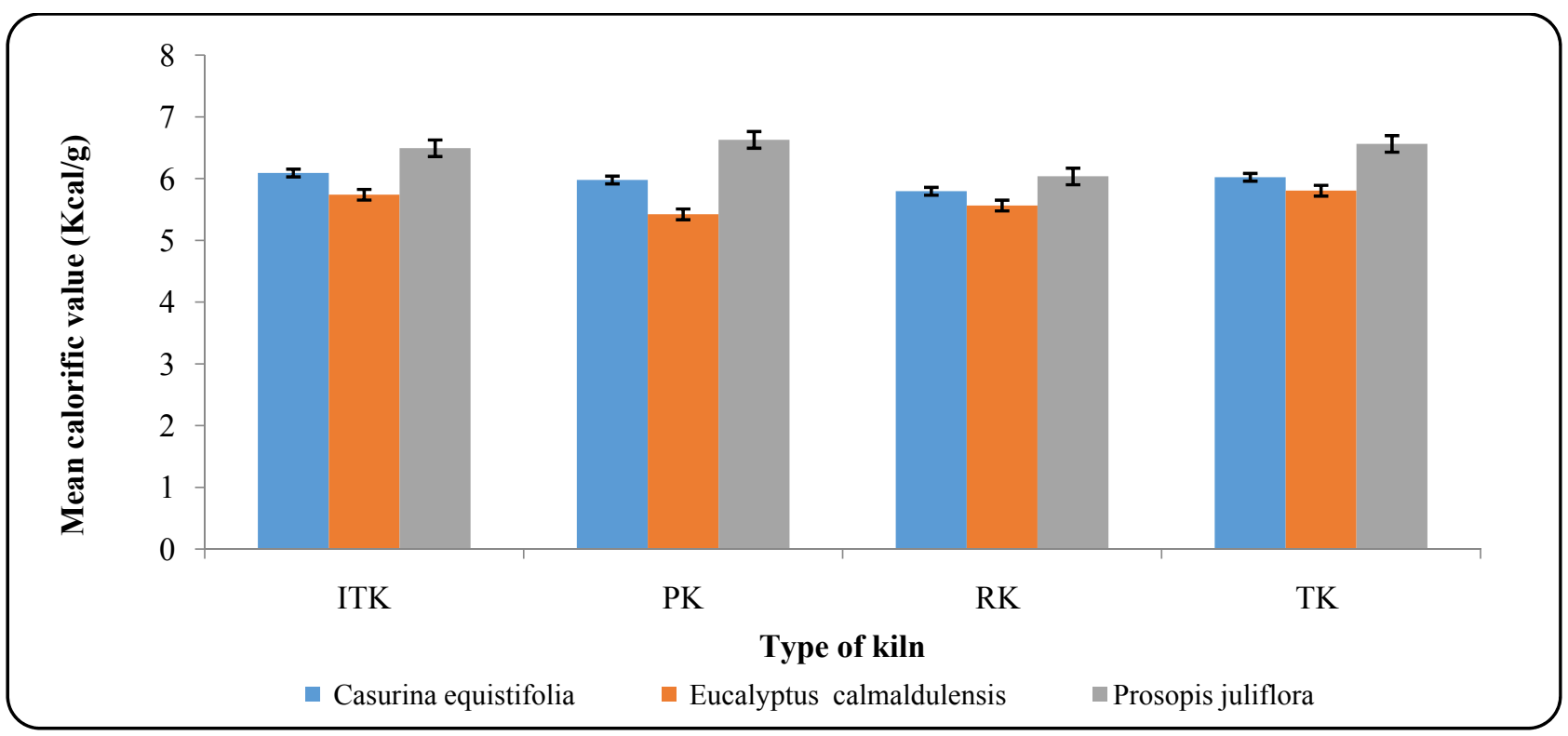

Fig. 7 Graphic presentation of calorific values of three exotic species carbonized using different kilns.

Note: ITK—Improved Earth Kiln; PK—Portable Kiln; RK—Retort Kiln; TK—Traditional Kiln. 


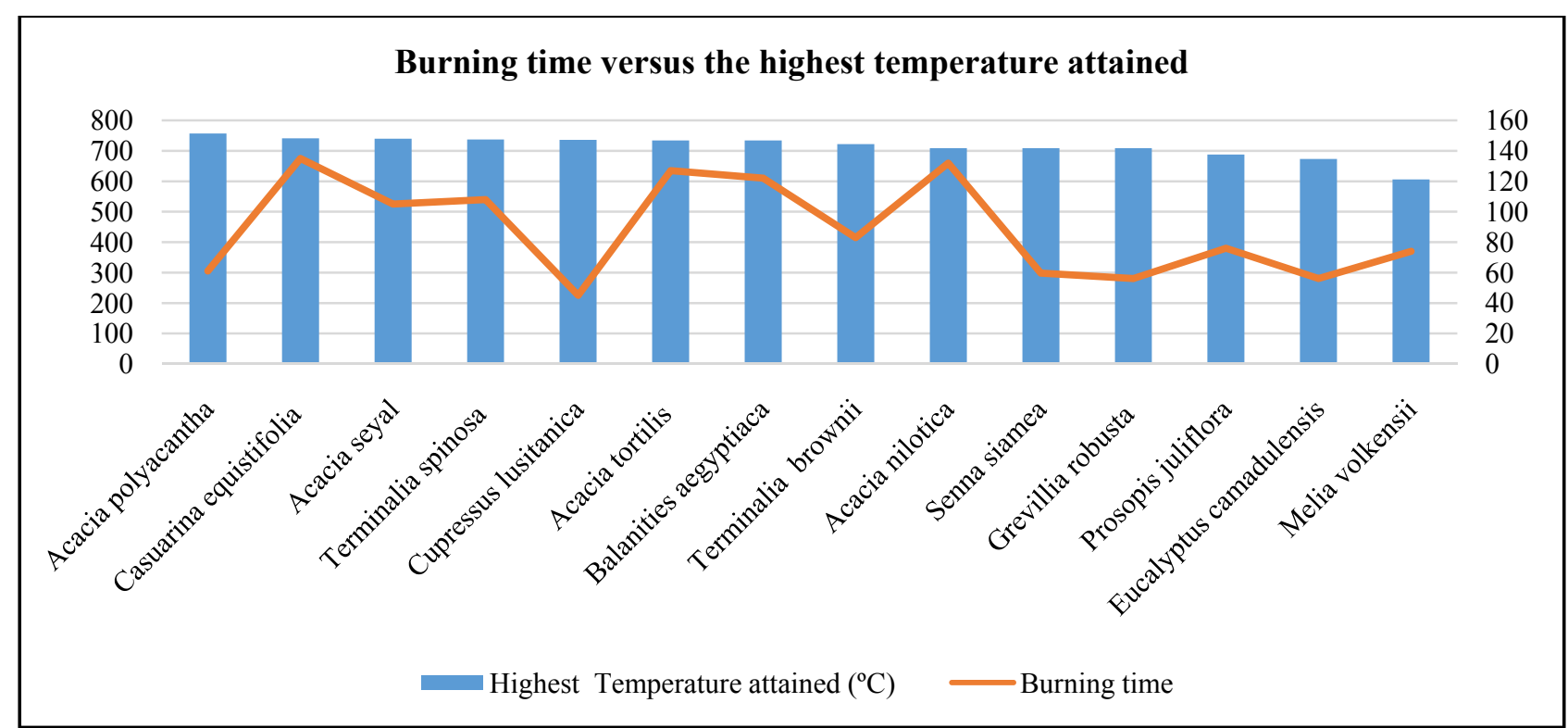

Fig. 8 Charcoal burning time versus the highest temperature attained.

Examples of species that had high temperature and long burning time were Balanities aegyptiaca, Casuarina esuisitifolia and Acacia tortilis. This confirms their high preference to the consumers.

\section{Conclusions}

Exotic species have comparable calorific values to wood from indigenous species and however, burn faster in cook stoves. The study showed that types of charcoal conversion technologies have no significant effect on the energy values (calorific values) of preferred species. The charcoal produced was generally within the ranges of a good quality charcoal, however, the physical characteristic and density of the charcoal were good among charcoal produced from improved kilns. The challenge of charcoaling wood with high moisture content did not produce the best recovery rates with all kiln types. This was especially so for the drum kiln and Adams Retort, which had to necessitate lighting them several times. Emission levels for all kilns were still high. Carbon Monoxide (CO) levels could not be measured for they were above measurable levels for the emission analyzer used.

\section{Recommendations}

Preferred indigenous species chosen for charcoal production should be conserved and domesticated to reduce loss of biodiversity through selective harvesting. High wood moisture content affects the efficiency of kilns, therefore wood materials for charcoal should be dried to about $20 \%$ moisture content. The study recommends the need to create awareness on the need for increased adoption of improved technologies with high recovery. There is need to conduct more research work on the effect of moisture content on the performance of the various improved charcoal conversion technologies in relation to kiln efficiency, quality of charcoal and greenhouse emission levels. The study recommends further research on all improved charcoal conversion technologies for reduced emission of greenhouse gases especially use of the retort kiln for complete combustion.

\section{Acknowledgement}

The authors wish to thank the KEFRI (Kenya Forestry Research Institute) Management and TNC (The Nature Conservancy) for logistical and financial support during the study. Authors also recognize and appreciate the KEFRI Kitui technical Staff who participated in the field work and data collection. Sincere appreciation goes to TNC for giving the 
KEFRI's National Forest Products Research Programme (Karura) an opportunity to carry out the study.

\section{References}

[1] Rehfuess, E. A., Bruce, N. G., and Smith, K. R. 2011. "Solid Fuel Use: Health Effect." In Encyclopedia of Environmental Health, v. 5, edited by J. O. Nriagu. Burlington: Elsevier, pp. 150161.

[2] Quinn, A. K., Bruce, N., Puzzolo, E., Dickinson, K., Sturke, R., Jack, D. W., et al. 2018. "An Analysis of Efforts to Scale Up Clean Household Energy for Cooking around the World." Energy for Sustainable Development 46: 1-10. https://doi.org/10.1016/j.esd.2018.06.011.

[3] Republic of Kenya. 2011. Scaling-up Renewable Energy Program (SREP) Investment plan for Kenya, Draft May 2011. Nairobi.

[4] GACC. 2013. Kenya Consumer Segmentation Study-Phase 1. A research Report by The Global Alliance for Clean Cook Stoves.

[5] Githiomi, J., and Oduor, N. 2012. "Strategies for Sustainable Wood Fuel Production in Kenya." International Journal of Applied Science and Technology 2 (10): 12.

[6] World Bank/Kenya Bureau of Statistics. 2012. International Energy Statistics Database. Kenya Data Portal.

[7] Republic of Kenya (ROK). 2013. Analysis of the Charcoal Value Chain in Kenya. Nairobi: Ministry of Environment, Water and Natural Resources.

[8] Oduor, N. 2012. Sustainable Feedstock Management for
Charcoal Production in Kenya. A Production of Practical Action Consulting. UK: Practical Action Consulting, p. 65.

[9] Oduor, N., Githiomi, J., Chikamai, B., and Kimwemwe, J. 2006. Charcoal Production Using Improved Earth, Portable Metal, Drum and the Casamance Kilns. Nairobi, Kenya: Downtown Publishers, p. 28.

[10] KEFRI. 2006. Charcoal Production Using Improved Earth, Portable Metal Drum and Casamance Kilns. Nairobi: PaperLine Limited.

[11] Kitheka, E. M., Kimiti, J. M., Oduor, N., and Mutinda, W. J. 2017. "Adoption of Biomass Energy Conservation Technologies in Selected Areas in Kitui County, Kenya." In Proceedings of the $3 r d$ DeKUT International Conference on STI\&E, 1st-3rd November, 2017.

[12] Giathi, G., Kitheka, E., Kiama, S., Sheikh, M., Bala, P., Githiomi, J., et al. 2016. "Tree Species Composition and Diversity in Areas of High Charcoal Production in Kitui County: A Case in Ikutha and Mwingi Sub-Counties." In Proceedings of the National Conference on Sustainable Land Management, Nakuru County, 1-4th June 2016.

[13] Ndegwa, G. M., Nehren, U., Grüninger, F., Iiyama, M., and Anhuf, D. 2016. "Charcoal Production through Selective Logging Leads to Degradation of Dry Woodlands: A Case Study from Mutomo District, Kenya." Journal of Arid Land 8 (4): 618-31. doi: 10.1007/s40333-016-0124-6.

[14] FAO Forestry Paper 63. 1985. Industrial Charcoal Making. Mechanical Wood Products Branch, Forest Industries Division. Food and Agriculture Organization (FAO) Forestry Department. FAO UN Rome 1985. www.fao.org/docrep. 